\title{
High-Performance Anion-Exchange Chromatography Coupled with Pulsed Electrochemical Detection as a Powerful Tool to Evaluate Carbohydrates of Food Interest: Principles and Applications
}

\author{
Claudio Corradini, Antonella Cavazza, and Chiara Bignardi \\ Dipartimento di Chimica Generale de Inorganica, Chimica Analitica, Chimica Fisica, Università Degli Studi di Parma, \\ Parco Area delle, Scienze 17/A, 43124 Parma, Italy \\ Correspondence should be addressed to Claudio Corradini, claudio.corradini@unipr.it
}

Received 18 December 2011; Accepted 23 February 2012

Academic Editor: Margarita Stoytcheva

Copyright ( $) 2012$ Claudio Corradini et al. This is an open access article distributed under the Creative Commons Attribution License, which permits unrestricted use, distribution, and reproduction in any medium, provided the original work is properly cited.

Specific HPLC approaches are essential for carbohydrate characterization in food products. Carbohydrates are weak acids with $\mathrm{p} K_{a}$ values in the range 12-14 and, consequently, at high $\mathrm{pH}$ can be transformed into oxyanions, and can be readily separated using highly efficient anion-exchange columns. Electrochemical detection in HPLC has been proven to be a powerful analytical technique for the determination of compounds containing electroactive groups; pulsed amperometric detection of carbohydrates is favourably performed by taking advantage of their electrocatalytic oxidation mechanism at a gold working electrode in a basic media. High-performance Anion Exchange Chromatography (HPAEC) at high pH coupled with pulsed electrochemical detection (PED) is one of the most useful techniques for carbohydrate determination either for routine monitoring or research application. This technique has been of a great impact on the analysis of oligo- and polysaccharides. The compatibility of electrochemical detection with gradient elution, coupled with the high selectivity of the anion-exchange stationary phases, allows mixtures of simple sugars, oligo- and polysaccharides to be separated with high resolution in a single run. A few reviews have been written on HPAEC-PED of carbohydrates of food interest in the last years. In this paper the recent developments in this field are examined.

\section{Introduction}

The analysis of carbohydrates in food has extreme nutritional importance because they are a primary source of energy and have healthy beneficial effects resulting mainly from dietary fibers and other unavailable carbohydrates resistant to digestion. In food industry they are largely used as technological coadjuvants in order to obtain physicochemical and selected sensorial characteristics for some products. Moreover, they are suitable to be considered as markers for quality and authenticity control.

Several analytical techniques have been proposed for carbohydrates analysis; among them, high-performance liquid chromatography (HPLC) coupled to different detection systems. This technique offers the advantages of high resolution, fast analysis, direct injection of the sample without or with little pretreatment, and easy of automation. Different operation modes of HPLC have been applied to the analysis of carbohydrates of food interest.

HPLC of carbohydrates is frequently performed using cation-exchange resins based on copolymers in protonated or metal ion forms. Metal-loaded strong cation exchangers such as sulphonated styrene-divinylbenzene copolymers in calcium, lithium, sodium, lead, and silver form, have been extensively used in many separations of mono- and oligosaccharides. Loading of sulfonated resins with various cations causes substantial changes in retention and selectivity of neutral carbohydrates. By these approaches separations 
are obtained involving different mechanisms such as ion exchange, ion exclusion, size exclusion, ligand exchange, and counterions in which underivatized saccharides are usually chromatographed using plain water as the mobile phase $[1,2]$.

Hydrophilic interaction chromatographic systems using bonded-phase packaging-based silica columns and employing acetonitrile-water mixtures as the mobile phase, as well as reversed-phase chromatography, have also been used for carbohydrate separation.

However, these modes of carbohydrate HPLC can suffer several drawbacks such as instability and short lifetime of the bonded phases and poor column performance in selectivity and efficiency. Furthermore, sensitive detection of carbohydrates after HPLC separation represents an additional difficulty for their determination; in fact carbohydrates mainly lack the chromophores and fluorophores. This often results in attempts to detect carbohydrates using lowwavelength UV absorbance or refractive index detection (RI). As it is well known, neutral carbohydrates adsorb only in the region $190-210 \mathrm{~nm}$, where the organic mobile phase modifiers such as acetonitrile also adsorb strongly, and consequently the UV detection is unsuitable for use in HPLC of underivatized carbohydrates in mobile phases rich in these solvents. A greater sensitivity of detection can be achieved by derivatization introducing either a chromophoric or a fluorescent group into carbohydrate analytes [3]. Moreover, post- and precolumn chemical derivatizations often enhance the selectivity of the detection since only reducing sugars can be modified in the presence of amino acids and lipids when carbonyl groups are derivatized. Either indirect UV absorbance or indirect fluorescence detection has also been proposed. After absorbance and fluorescence, refractive index (RI) detection is the third mode in order of importance in conventional HPLC, and it has been the most frequently used in HPLC of carbohydrates. However, the major disadvantage of RI detection is its sensitivity to changes in mobile phase composition, preventing its use when gradient elution is employed.

Consequently, the lack of selectivity and sensitivity of these detection modes is often not sufficient for the analysis of carbohydrates present in complex mixtures such as food. Alternatively, evaporative light-scattering detection (ELSD) has also been proposed. ELSD is insensitive to temperature fluctuations, allows gradient solvent systems, and is dependent on the mass of the vaporized analyte. On the other hand, ELSD requires the vaporization of all the components of the HPLC eluent and the nonvaporization of carbohydrates which can be detected. It is thus possible to use any gradient of eluents requiring the lowest possible temperature to prevent thermal degradation of carbohydrates. Consequently, the chromatographic mobile phase composition is not independent from the detection system. In conclusion, ELSD detection, which can be considered a universal detector, found scarce application in HPLC analysis of carbohydrates.

High-performance anion-exchange chromatography (HPAEC) is a powerful analytical tool in carbohydrate separation due its ability to separate all classes of alditols, aminosugars, mono-, oligo- and polysaccharides, according to structural features such as size, composition, anomericity and linkage isomerism. Moreover, detector insensitivity is overcome coupling HPAEC with pulsed amperometric detection. HPAEC-PED is presently being applied to a variety of routine monitoring and research applications. Moreover, this technique has had a major impact on the analysis of oligo-, and polysaccharides. The compatibility of electrochemical detection with gradient elution coupled with the high selectivity of the anion-exchange stationary phases allows mixtures of simple sugars, oligo- and polysaccharides to be separated with suitable resolution in a single run.

\section{High-Performance Anion-Exchange Chromatography (HPAEC)}

Anion exchange chromatography is not a technique commonly associated with the analysis of neutral carbohydrates. However, many carbohydrates are weak acids with $\mathrm{p} K_{\mathrm{a}}$ values in the range $12-14$, and, consequently, at high $\mathrm{pH}$ values their hydroxyl groups are partially or totally transformed into oxyanions, enabling this class of compounds to be selectively eluted as anions by high-performance anionexchange chromatography in a single run.

Under alkaline conditions, carbohydrates are readily separated by quaternary-ammonium-bonded pellicular anionexchange columns, where the order of increasing retention is correlated with decreasing $\mathrm{p} K_{\mathrm{a}}$ value.

Anion exchange chromatography on high $\mathrm{pH}$-resistant polymeric-based strong anion-exchange columns specifically tailored for carbohydrate analysis enables selective elution of carbohydrates, where the most important parameters influencing the separations are the number of hydroxyl groups, anomerism, positional isomerism and the polymerization degree. Monosaccharides possess several potentially ionisable hydroxyl groups having, taking glucose as reference, the following hierarchy of acidity: $1-\mathrm{OH}>2-\mathrm{OH} \geq 6-\mathrm{OH}>3-\mathrm{OH}>4-\mathrm{O}$.

aldoses exhibit greater retention than their reduced alditol forms. A study conducted by Paskach et al. [4] on the retention behavior of 93 alditols and carbohydrates on HPAEC has demonstrated that capacity factors for monosaccharides are lowest for the alditols and are higher and approximately similar for analogous aldoses and ketoses. There is a general trends, observed to be strongest with alditols, for capacity factors to increase with increasing numbers of carbon atoms. The most common columns employed in HPAEC-PED, specifically designed for carbohydrate anion-exchange chromatography, are manufactured by Dionex (Sunnyvale, CA, USA; now Thermo Fisher Scientific Inc., USA). As reported in Table 1, the CarboPac MA1 is a macroporous resin fully functionalized with a high-capacity, strong exchange column, whereas the others are prepared by proprietary processes, which permit the independent manufacture of polymeric nonporous sulphonated resins and anion-exchange latex particles functionalized with quaternary ammonium compounds that are brought together only at the last steps of preparing anion-exchanger columns. 
TABLE 1: Most employed columns for HPAEC-PAD analysis*.

\begin{tabular}{|c|c|c|c|}
\hline Column & Specifications & Samples & Notes \\
\hline $\begin{array}{l}\text { CarboPac } \\
\text { MA1 }\end{array}$ & $\begin{array}{l}7.5 \mu \mathrm{m} \text { diameter } \\
\text { vinylbenzylchloride-divinylbenzene } \\
\text { macroporous substrate fully } \\
\text { functionalized with alkyl quaternary } \\
\text { ammonium groups ( } 15 \% \text { crosslinked })\end{array}$ & $\begin{array}{l}\text { Reduced mono- and } \\
\text { disaccharide alditol } \\
\text { analyses }\end{array}$ & $\begin{array}{c}\text { Other carbohydrates: } \\
\text { fucose, } \\
\text { N-acetyl-(D)-glucosamine, } \\
\text { N-acetyl-galactosamine, } \\
\text { mannose, galactose }\end{array}$ \\
\hline $\begin{array}{l}\text { CarboPac } \\
\text { PA1 }\end{array}$ & $\begin{array}{l}10 \mu \mathrm{m} \text { diameter substrate (polystyrene } \\
2 \% \text { crosslinked with divinylbenzene) } \\
\text { agglomerated with MicroBead } \\
\text { quaternary ammonium functionalized } \\
\text { latex ( } 5 \% \text { crosslinked) }\end{array}$ & $\begin{array}{l}\text { Mono- and } \\
\text { disaccharides, } \\
\text { oligosaccharides }\end{array}$ & $\begin{array}{l}\text { Column well suited for the } \\
\text { analysis of food for } \\
\text { nutrition labelling }\end{array}$ \\
\hline $\begin{array}{l}\text { CarboPac } \\
\text { PA10 }\end{array}$ & $\begin{array}{l}10 \mu \mathrm{m} \text { diameter substrate } \\
\text { (ethylvinylbenzene } 55 \% \text { cross linked } \\
\text { with divinylbenzene) agglomerated } \\
\text { with a } 460 \mathrm{~nm} \text { MicroBead difunctional } \\
\text { quaternary ammonium ion ( } 5 \% \\
\text { crosslinked) }\end{array}$ & $\begin{array}{l}\text { Mono- and } \\
\text { disaccharides, } \\
\text { glucosamine, } \\
\text { galactosamine; sialic } \\
\text { acids }\end{array}$ & $\begin{array}{l}\text { Ideal for the analysis of } \\
\text { mono- and disaccharides in } \\
\text { foods, drugs, and plants }\end{array}$ \\
\hline $\begin{array}{l}\text { CarboPac } \\
\text { PA20 }\end{array}$ & $\begin{array}{l}6.5 \mu \mathrm{m} \text { diameter substrate } \\
\text { (ethylvinylbenzene } 55 \% \text { crosslinked } \\
\text { with divinylbenzene) agglomerated } \\
\text { with a } 130 \mathrm{~nm} \text { MicroBead difunctional } \\
\text { quaternary ammonium ion ( } 5 \% \\
\text { crosslinked) }\end{array}$ & $\begin{array}{l}\text { Mono- and } \\
\text { disaccharides }\end{array}$ & $\begin{array}{l}\text { High resolution regarding } \\
\text { the six monosaccharides } \\
\text { commonly found in } \\
\text { mammalian glycoproteins }\end{array}$ \\
\hline $\begin{array}{l}\text { CarboPac } \\
\text { PA100 }\end{array}$ & $\begin{array}{l}8.5 \mu \mathrm{m} \text { diameter substrate } \\
\text { (ethylvinylbenzene } 55 \% \text { crosslinked } \\
\text { with divinylbenzene) agglomerated } \\
\text { with a } 275 \mathrm{~nm} \text { MicroBead quaternary } \\
\text { amine functionalized latex ( } 6 \% \\
\text { crosslinked) }\end{array}$ & $\begin{array}{c}\text { Separation of closely } \\
\text { related oligosaccharides, } \\
\text { oligosaccharides released } \\
\text { from glycoproteins } \\
\text { which can differ in size, } \\
\text { charge, branching, and } \\
\text { linkage }\end{array}$ & $\begin{array}{l}\text { Separation of neutral and } \\
\text { charged oligosaccharides in } \\
\text { the same run } \\
\text { Separation of closely } \\
\text { related oligosaccharides }\end{array}$ \\
\hline $\begin{array}{l}\text { CarboPac } \\
\text { PA200 }\end{array}$ & $\begin{array}{l}5.5 \mu \mathrm{m} \text { diameter substrate } \\
\text { (ethylvinylbenzene } 55 \% \text { crosslinked } \\
\text { with divinylbenzene) agglomerated } \\
\text { with a } 43 \mathrm{~nm} \text { MicroBead quaternary } \\
\text { amine functionalized latex ( } 6 \% \\
\text { crosslinked) }\end{array}$ & Oligosaccharides & $\begin{array}{l}\text { Separations based on size, } \\
\text { charge, degree of } \\
\text { branching, and linkage } \\
\text { isomerism }\end{array}$ \\
\hline $\begin{array}{l}\text { CarboPac } \\
\text { SA10 }\end{array}$ & $\begin{array}{l}6.0 \mu \mathrm{m} \text { diameter substrate } \\
\text { (ethylvinylbenzene } 55 \% \text { crosslinked } \\
\text { with divinylbenzene) agglomerated } \\
\text { with a } 55 \mathrm{~nm} \text { MicroBead quaternary } \\
\text { ammonium ion ( } 4.5 \% \text { crosslinked) }\end{array}$ & $\begin{array}{l}\text { Mono- and } \\
\text { disaccharides }\end{array}$ & $\begin{array}{c}\text { Fast analysis of mono- and } \\
\text { disaccharides of food } \\
\text { interest. }\end{array}$ \\
\hline
\end{tabular}

* As reported in technical note from Dionex (Thermo Fisher Inc.).

Monosaccharide separations are normally performed on CarboPac PA1 and CarboPac PA10 columns, which have high selectivity for mono- and disaccharide separations. These sugars are usually eluted isocratically using sodium hydroxide solutions at concentration ranging from 10 to $20 \mathrm{mM}$. Particular attention should be paid to the preparation of eluents in order to avoid the presence of carbon dioxide and subsequent production of carbonate in the mobile phase. Carbonate, being a divalent ion at $\mathrm{pH} \mathrm{12,} \mathrm{binds} \mathrm{strongly}$ to the anion exchangers and interferes with carbohydrate retention, causing shortened retention times, decrease in column selectivity, and loss in resolution. Efforts to solve this problem may rely on the use of an electrochemical generator of potassium hydroxide eluents which are not affected by carbonate interference. Cataldi and coworkers proposed the use of barium and strontium ions in the alkaline eluent for reducing the uptake of carbon dioxide [5].

The separation of closely related carbohydrates, such as glucose and mannose which differ only in the axialequatorial configuration of their hydroxyl groups, can be enhanced significantly by lowering the $\mathrm{pH}$ of the alkaline eluent to a value that is comparable to the $\mathrm{p} K_{\mathrm{a}}$ of the sugar molecules, namely $\mathrm{pH} 12$. In this case, postcolumn addition to the eluent stream of a strong base through a tee connection can provide the alkaline environment necessary for carbohydrate detection at the gold working electrode of the detector.

Retention of oligosaccharides on HPAEC column is not directly predictable by extrapolating the hierarchy of monosaccharide hydroxyl acidities to oligosaccharides. For 
TABLE 2: Gradient elution program employed for inulin analysis reported in Figure 1; flow $=0.50 \mathrm{~mL} / \mathrm{min}$.

\begin{tabular}{lccc}
\hline Time (minutes) & \% eluent $\mathrm{A} \mathrm{H}_{2} \mathrm{O}$ & \% eluent B NaOH $600 \mathrm{mM} \mathrm{50 \%}$ & \% eluent $\mathrm{C} \mathrm{NaNO}_{3} 500 \mathrm{mM}^{2}$ \\
\hline 0 & 83 & 16 & 4 \\
10 & 80 & 16 & 4 \\
10.1 & 80 & 16 & 4 \\
40 & 60 & 16 & 24 \\
\hline
\end{tabular}

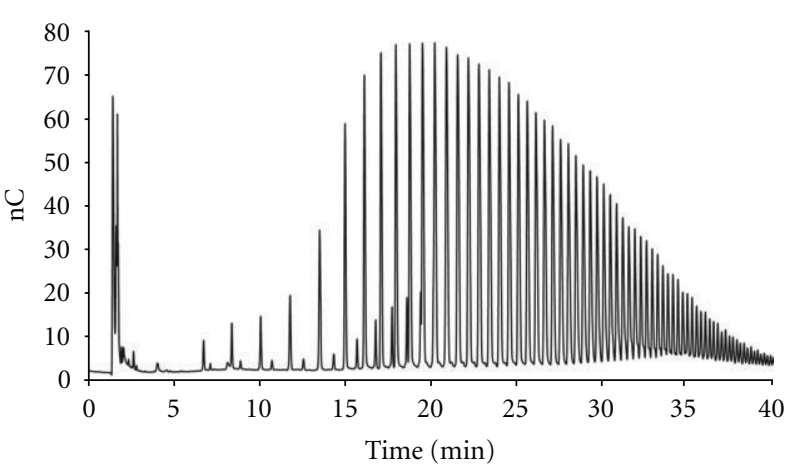

(a)

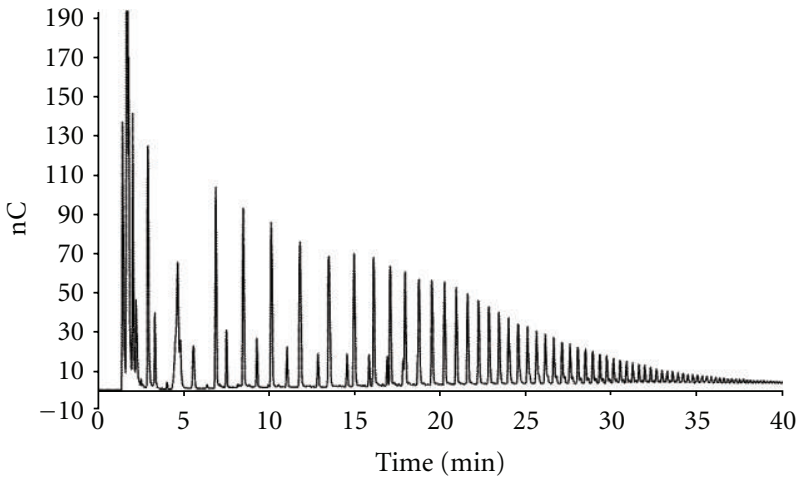

(b)

Figure 1: Chromatographic profiles obtained for Inulin Tex $0.5 \mathrm{mg} / \mathrm{mL}$ (a) and IQ $0.5 \mathrm{mg} / \mathrm{mL}$ (b) on a column CarboPac PA200 at the conditions of elution reported in Table 2.

members of homologous series of oligosaccharides, the capacity factors increase in a regular and predictable manner with chain length. However, beside chain length, other than saccharide composition, linkage positions are expected to affect the chromatographic retention of oligosaccharides.

Corradini et al. [6] showed that separation by HPAEC of twelve disaccharides was strongly affected, beside their acidity, by the accessibility of oxyanions to the functional groups of the anion exchanger column. This effect has been observed in particular for the glucobioses trehalose, isomaltose, gentiobiose, nigerose, and maltose, which are disaccharides composed of two D-glucosyl residues, differing only in the configuration of their glycosidic bonds.

The CarboPac PA100 and CarboPac PA200, strong anion exchange columns, are proposed for oligosaccharide characterization. To elute oligosaccharides and polysaccharide until DP 85, a stronger eluent than sodium hydroxide is needed. Sodium acetate solutions are usually employed for these separations that still require sodium hydroxide because a strongly basic environment is necessary for detection.

Most oligosaccharide separations are performed by sodium acetate gradient with a constant concentration of sodium hydroxide. The effects of acetate and nitrate as "pushing agent" have also been investigated. Wong and Jane [7] compared separations of debranched amylopectin achieved adding acetate or nitrate anions in the mobile phases. They found that, in comparison with the commonly used pushing agent, nitrate offered greater reproducibility, accuracy, and lower limit of detection.

More recently, we verified that an improvement in resolution with shorter chromatographic runs can be achieved using nitrate instead of acetate as the pushing agent in the mobile phase composition for the separation and detection of inulin by HPAEC-PED. The different chain-length distribution profiles of two commercial available inulins have been accomplished with the CarboPac PA200 column using nitrate as the "pushing agent" and gradient elution following the program reported in Table 2. Under the selected conditions, baseline separation was achieved in a short analysis time (see Figure 1).

\section{Pulsed Electrochemical Detection (PED)}

Electrochemical detection in HPLC has been proven to be a powerful analytical technique for the determination of compounds containing electroactive groups, and recently the progress in application of this detection strategy coupled to liquid chromatography has been reviewed by Trojanowicz [11].

Amperometric detection is typically performed at a solid anode, such as gold, platinum, and glassy carbon, under constant applied potential, which is denoted as DC amperometry. In constant potential amperometric mode-numerous aromatic compounds are easily detected by anodic reactions. These include phenols, aminophenols, catecholamines, and other metabolic amines.

The presence of $\pi$-resonance in aromatic compounds functions to stabilize intermediate oxidation products of anodic oxidation, and, as a consequence, the activation barrier for electrochemical reaction is significantly lowered. In dc amperometry, the electrode must be inert and able to accept or donate electrons to the analyte of interest. This is particularly true for glassy carbon electrodes which are particularly resistant to fouling. Glassy carbon 
is the most commonly used working electrode material in chromatographic amperometric detection, using a constant applied potential. In the case of carbohydrates, this system is not adequate since glassy carbon amperometric electrodes exhibit no response for aliphatic compounds. As expected, the absence of $\pi$-resonance for these compounds results in very low oxidation rates at an inert electrode, although the reactions may be favoured thermodynamically.

Considering that an inherent electronic stabilization mechanism does not exist for polar aliphatic compounds, the stabilization of the formed free-radical intermediates can be achieved with the use of catalytic electrode surfaces. Aldehyde and terminal alcohol moieties in carbohydrates can be oxidated at golden electrodes in alkaline media and at $\mathrm{Pt}$ electrodes under all $\mathrm{pH}$ conditions.

Electrocatalytic properties of gold electrodes are much less pronounced under acidic conditions, and only analytes with a strong affinity to gold, such as sulfur-containing species which are readily adsorbed on the gold surface, are oxidized and detected on gold electrodes under these conditions. However, intermediate oxidation products of analytes can adsorb on the surface of solid electrodes with direct participation of the electrode surface within the oxidation mechanisms. Unfortunately, a serious consequence of adsorption is the fouling of the electrode by accumulation of reaction products, resulting in the gradual loss of electrode response. The problem of electrode fouling can be solved by application of a pulsed potential waveform.

The application of alternated positive and negative potential pulses as a method in reactivating $\mathrm{Au}$ and $\mathrm{Pt}$ electrodes that have become fouled by adsorption of organic compounds has been employed since the early part of the last century [12].

Pulsed amperometric detection (PAD) applying a repetitive three-step waveform was proposed the first time in 1981 for the detection of simple alcohols at Pt electrodes in flow-injection systems $[13,14]$. In these applications anodic detection was alternated with oxidative cleaning by stepping the potential to a greater positive value and reductive cleaning of adsorbed products for the reactivation of noblemetal electrodes to maintain a reproducibly high electrode activity. By utilizing a simple three-step potential waveform, reproducible detection of polar aliphatic compounds can be achieved. This technique had been popularly known as pulsed amperometric detection (PAD).

This detection approach was particularly attractive in combination with high-performance anion-exchange chromatography using quaternary ammonium polymer-based stationary phases and high $\mathrm{pH}$.

In Figure 2 is reported a generic triple-pulse potential waveform designed for detection of carbohydrate at a gold electrode in alkaline media. As shown in the figure, detection occurs at a constant potential $E_{1}$, which is applied for the time $t_{1}$ with electronic integration of the current during the period $t_{\text {int }}$, following a delay of $t_{\text {del }}$ to allow changing current to decay to a negligible value $\left(t_{1}=t_{\text {del }}+t_{\text {det }}\right)$. The potential of the electrode is then increased from $E_{1}$ to $E_{2}$ (with $E_{2} \gg E_{1}$ ), during a period $t_{2}$ to fully oxidize any absorbed impurities and/or detect products on the electrode

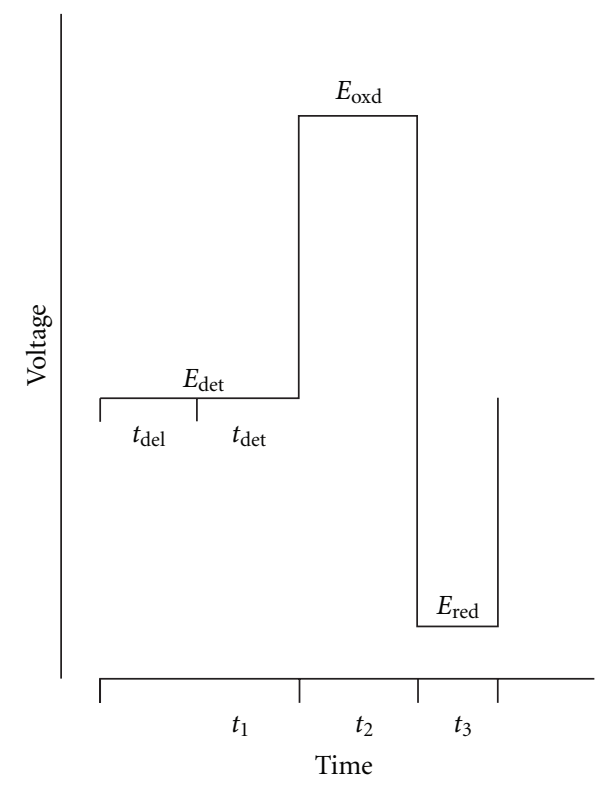

FIgURE 2: Triple-pulsed potential waveform designed for detection of carbohydrates. Qualitative waveform, where $E_{\text {det }}$ is the constant potential $E_{1}$, applied for the time $t_{1} E_{\text {oxd }}$ is referred to potential $E_{2}$ (fully oxidation on the working gold electrode), applied for the time $t_{2} ; E_{\text {red }}$ is the negative potential applied during the time $t_{3}$ to convert the gold oxide back to native metal.

surface. This oxidation step generates the formation of a thin layer of oxide on the electrode surface. The applied voltage on the electrode is then reversed to a strongly reducing potential $\left(E_{3} \ll E_{1}\right)$ during the period $t_{3}$, which convert the noblemetal oxide layer at the surface of the electrode back to native metal, thus renewing the electrode surface. Following a delay during which charging current resulting from the step from the final potential $\left(E_{3}\right)$ back to the initial potential $\left(E_{1}\right)$ decays, analyte oxidation current is measured by integration for a fixed duration, $t_{\text {det }}$ depicted in Figure 2 . The resulting measured charge, expressed in micro-Coulomb, obtained from the analyte integration current, is proportional to the rate of the oxidation reaction.

PAD detection can be defined with the more generic name of "pulsed electrochemical detection" (PED). The measurement of the current in PED instrumentation is due by electronic integration of electrode current during the period $t_{\text {int }}$ (see Figure 2). Hence, the output voltage signal can be directly proportional to the average current or to the current integral [12].

The former style of signal presentation has resulted in the common name "pulsed amperometric detection" (PAD), whereas the names of "pulsed coulometric detection" and "integrated pulsed amperometric detection" (IPAD) have been suggested for the later style of the signal presentation [15].

Sensitivity of PED detection of alditols, monosaccharides, oligosaccharides, and polysaccharides at gold electrodes is maximized under alkaline conditions $(\mathrm{pH}>12)$, which are also the chromatographic conditions requested in HPAEC. 
Pulsed potential waveform optimization to determine the appropriate detection potential in HPAEC-PED is usually performed by cyclic voltammetry; the choice of the potential and time parameters in PED waveforms have been extensively reviewed $[12,16]$.

Improvement of long-term reproducibility of pulsed amperometric detection of carbohydrate has been achieved applying a quadruple-potential waveform to the working gold electrode in the flow-through detector cell instead of the triple-pulse potential waveform [17]. With the new selected waveform, a negative cleaning and a positive activation potentials maintain a clean and active gold electrode surface without causing electrode corrosion, with its consequent recession. Recession of the working gold electrode increases the volume between the working electrode and the counter electrode, decreasing the linear velocity of flow over the surface of the working electrode. This causes decreased transport of analyte to the electrode and consequent decreased detector response.

The proposed quadruple-potential waveform maximizes signal-to-noise ratio, showing similar minimum detection limits obtained employing with the triple-potential waveform, but greatly improving long-term reproducibility.

Since its introduction, pulsed electrochemical detection has considerably improved the sensitivity and selectivity of the separation of carbohydrates by HPAEC using alkaline mobile phases. The alkaline conditions are appropriate for the direct detection of carbohydrate by PED at gold electrode.

HPAEC coupled with PED detection has proven to be a very useful method for the analysis of the carbohydrates, including those of food interest. Applications regarding HPAEC-PED of carbohydrates determination in several food products such as fruit juices, milk, soluble instant coffee, infant formulas, dietetic candy, chocolate, honey, wine, wheat, rice, barley, sweet potato, corn syrups, and so on have been extensively reviewed by Cataldi and coworkers in the year 2000 [18] and by El Rassi in 2002 [19].

\section{Recent Applications of HPAEC-PAD in Food Analysis}

Food carbohydrates come in two principal groups: simple carbohydrates and complex carbohydrates. Simple carbohydrates consist of any soluble, digestible, and absorbable sugar such as monosaccharides, disaccharides, and sugar alcohols or alditols. Complex carbohydrates comprise the oligosaccharides and polysaccharides, such as starch and fiber components.

The analysis of carbohydrates in food is of great importance for many studies related to several sectors of investigation such as compositional evaluation, estimation of the nutritional value of a food product, food technology and food processing, control of food origin, authenticity, and eventual adulterations, monitoring of a product during storage.

In Table 3 a list of applications of HPAEC-PAD for the analysis of food products performed in the late years is reported, with the related references [8-10, 20-56]. As can be seen, the analytes most studied have been oligosaccharides rather than simple sugars.

While the main impact of carbohydrates occurrence in a food preparation is linked to the sweetener effect related to the presence of mono- and disaccharides, the occurrence of oligo- and polysaccharides gives to the food different properties depending on the type of linkage between the monomeric units that may be attacked by the human enzymes or not.

Fructooligosaccharides (FOSs) and inulin can be defined as nondigestible food ingredients and are effective prebiotics, which beneficially affect the host by selectively stimulating the growth and/or activity of the microbial groups. They occur naturally in many foods of vegetable origin, such as onions, Jerusalem artichokes, asparagus, leeks, garlic, and chicory.

FOSs are composed by chains of fructose moieties linked by $\beta$ - $(2 \rightarrow 1)$-glycosidic bonds with or without a terminal glucose unit. FOS has a degree of polymerization (DP) of 2-9 and is produced from inulin by controlled hydrolysis. Inulin is extracted from chicory roots and contains fructose chains ranging in DP from 3 to 80.

FOS and inulin pass the stomach and small intestine unaltered, since they cannot be degraded or absorbed, and reach the colon where they are fermented by the intestinal microbiota exhibiting favorable effects on health promoting the growth of enteral bacteria, the intestinal motility, and the stimulation of the immune response [57].

HPAEC-PED has been demonstrated by Corradini et al. [58] to be a powerful tool to evaluate changing in chain length distribution of FOS and inulin fermented by bifidobacteria, providing significant information about their prebiotic capabilities. Fermentation of oligo- and polysaccharides in the colon is the result of a complex microbial metabolic activity, and long inulin chains are hydrolysed by extracellular enzymes, supplying FOS to bifidobacteria for selective growth [59].

Besides, inulin is widely used in food formulation for its technological properties on texture: inulin can develop a gel-like structure when mixed with aqueous liquid, forming a gel with creamy appearance. Therefore, it can be easily incorporated into food as sugar and fat replacer, and it is often used as ingredient in the so-called functional foods.

The traditional and the official analytical methods for inulin and oligosaccharides are based on enzymatic assays. Those systems are long-time consuming and give results related only to the total sugar content, by quantification of the monosaccharidic units, without providing any information about chains distribution and DP. On the other hand, HPAEC-PAD has been reported to show the advantage of giving a signal for any single chain of different DP [60] and provide useful information on chain length distribution [4], a parameter of great importance for the physicochemical properties of these compounds when used as food ingredients.

The ability of commercial available inulins with different oligo- and polysaccharide profile to form gel was recently investigated by Chiavaro et al. [61]. The knowledge of 
TABLE 3: Recent applications of HPAEC-PAD in food analysis.

\begin{tabular}{|c|c|c|c|c|}
\hline Food sample & Analytes & Column & Eluent & Ref. \\
\hline & Galactooligosaccharides (GOSs) & $\begin{array}{l}\text { CarboPac } \\
\text { PA1 }\end{array}$ & $\mathrm{NaOH}, \mathrm{CH}_{3} \mathrm{COONa}$ & {$[20]$} \\
\hline & $\begin{array}{l}\text { Mixture of neutral } \\
\text { oligosaccharides }\end{array}$ & $\begin{array}{l}\text { CarboPac } \\
\text { PA100 }\end{array}$ & $\mathrm{NaOH}, \mathrm{CH}_{3} \mathrm{COONa}$ & {$[21]$} \\
\hline Agave & Fructooligosaccharides (FOSs) & $\begin{array}{l}\text { CarboPac } \\
\text { PA100 }\end{array}$ & $\mathrm{NaOH}, \mathrm{CH}_{3} \mathrm{COONa}$ & {$[22]$} \\
\hline Agave americana & Fructans & $\begin{array}{c}\text { CarboPac } \\
\text { PA10, } \\
\text { CarboPac } \\
\text { PA200 }\end{array}$ & $\mathrm{NaOH}, \mathrm{CH}_{3} \mathrm{COONa}$ & {$[23]$} \\
\hline Agave tequilana & $\begin{array}{l}\text { Water-soluble carbohydrate } \\
\text { composition }\end{array}$ & $\begin{array}{l}\text { CarboPac } \\
\text { PA100 }\end{array}$ & $\mathrm{NaOH}, \mathrm{CH}_{3} \mathrm{COONa}$ & {$[24]$} \\
\hline Artichoke & Inulooligosaccharides (IOSs) & $\begin{array}{l}\text { CarboPac } \\
\text { PA100 }\end{array}$ & $\mathrm{NaOH}, \mathrm{CH}_{3} \mathrm{COONa}$ & {$[25]$} \\
\hline Banana & Fructooligosaccharides (FOSs) & $\begin{array}{l}\text { CarboPac } \\
\text { PA1 }\end{array}$ & $\mathrm{NaOH}, \mathrm{CH} 3 \mathrm{COONa}$ & {$[26]$} \\
\hline Barley & Oligosaccharides & $\begin{array}{l}\text { CarboPac } \\
\text { PA1 }\end{array}$ & $\mathrm{NaOH}, \mathrm{CH} 3 \mathrm{COONa}$ & {$[27]$} \\
\hline Brewer's spent grain & Oligosaccharides & $\begin{array}{l}\text { CarboPac } \\
\text { PA1 }\end{array}$ & $\mathrm{NaOH}, \mathrm{CH}_{3} \mathrm{COONa}$ & {$[28]$} \\
\hline Dietary supplements & Maltose & $\begin{array}{l}\text { CarboPac } \\
\text { PA1 }\end{array}$ & $\mathrm{NaOH}, \mathrm{CH}_{3} \mathrm{COONa}$ & {$[29]$} \\
\hline $\begin{array}{l}\text { Fermented beverage of } \\
\text { plant extract }\end{array}$ & Oligosaccharides & $\begin{array}{l}\text { Carbo Pac } \\
\text { PA1 }\end{array}$ & $\mathrm{NaOH}, \mathrm{CH}_{3} \mathrm{COONa}$ & {$[30]$} \\
\hline $\begin{array}{l}\text { Fermented beverage of } \\
\text { plant extract }\end{array}$ & Fructopyranose oligosaccharides & $\begin{array}{l}\text { Carbo Pac } \\
\text { PA1 }\end{array}$ & $\mathrm{NaOH}, \mathrm{CH}_{3} \mathrm{COONa}$ & {$[31]$} \\
\hline $\begin{array}{l}\text { Fermented beverage of } \\
\text { plant extract }\end{array}$ & Oligosaccharides & $\begin{array}{l}\text { CarboPac } \\
\text { PA1 }\end{array}$ & $\mathrm{NaOH}, \mathrm{CH}_{3} \mathrm{COONa}$ & {$[32]$} \\
\hline Fermented milk & Galactooligosaccharides (GOSs) & $\begin{array}{l}\text { CarboPac } \\
\text { PA1 }\end{array}$ & $\mathrm{NaOH}, \mathrm{CH}_{3} \mathrm{COONa}$ & {$[33]$} \\
\hline Fermented milk & $\begin{array}{l}\text { Fructooligosaccharides (FOSs), } \\
\text { inulooligosaccharides (IOSs) }\end{array}$ & $\begin{array}{l}\text { CarboPac } \\
\text { PA100 }\end{array}$ & $\mathrm{NaOH}, \mathrm{CH}_{3} \mathrm{COONa}$ & {$[8]$} \\
\hline $\begin{array}{l}\text { Fermented milk, Cooked } \\
\text { Ham, Food ingredients }\end{array}$ & $\begin{array}{l}\text { Fructooligosaccharides (FOSs) } \\
\text { and inulins }\end{array}$ & $\begin{array}{c}\text { CarboPac } \\
\text { PA100 } \\
\text { CarboPac } \\
\text { PA200 }\end{array}$ & $\begin{array}{c}\mathrm{NaOH}, \mathrm{CH}_{3} \mathrm{COONa} \\
\mathrm{NaOH}, \mathrm{NaNO}_{3}\end{array}$ & {$[34]$} \\
\hline Fermented milk (synbiotic) & $\begin{array}{l}\text { Fructooligosaccharides (FOSs), } \\
\text { inulooligosaccharides (IOSs) }\end{array}$ & $\begin{array}{l}\text { CarboPac } \\
\text { PA200 }\end{array}$ & $\mathrm{NaOH}, \mathrm{NaNO}_{3}$ & {$[35]$} \\
\hline Fruit juice & $\begin{array}{l}\text { Sucralose, fructooligosaccharides } \\
\text { (FOSs) }\end{array}$ & $\begin{array}{l}\text { CarboPac } \\
\text { PA1 }\end{array}$ & $\mathrm{NaOH}, \mathrm{CH}_{3} \mathrm{COONa}$ & {$[36]$} \\
\hline Grape & $\begin{array}{c}\text { Simple sugars, } \\
\text { fructooligosaccharides (FOSs) }\end{array}$ & $\begin{array}{l}\text { CarboPac } \\
\text { PA1 }\end{array}$ & $\mathrm{NaOH}, \mathrm{CH}_{3} \mathrm{COONa}$ & {$[37]$} \\
\hline Honey & Oligosaccharides & $\begin{array}{l}\text { CarboPac } \\
\text { PA100 }\end{array}$ & $\mathrm{NaOH}, \mathrm{CH}_{3} \mathrm{COONa}$ & {$[38]$} \\
\hline Honey & Oligosaccharides & $\begin{array}{l}\text { CarboPac } \\
\text { PA100 }\end{array}$ & $\mathrm{NaOH}, \mathrm{CH}_{3} \mathrm{COONa}$ & {$[9]$} \\
\hline Honey & $\begin{array}{c}\text { Monosaccharides, } \\
\text { Oligosaccharides }\end{array}$ & $\begin{array}{c}\text { CarboPac } \\
\text { PA1 } \\
\end{array}$ & $\mathrm{NaOH}$ & {$[39]$} \\
\hline Honey & Polysaccharides & $\begin{array}{l}\text { CarboPac } \\
\text { PA100 } \\
\end{array}$ & $\mathrm{NaOH}, \mathrm{CH}_{3} \mathrm{COONa}$ & {$[40]$} \\
\hline Instant coffee & Glucose, xylose & $\begin{array}{l}\text { CarboPac } \\
\text { PA1 } \\
\end{array}$ & $\mathrm{NaOH}$ & {$[41]$} \\
\hline Konjac & Glucomannan oligosaccharides & $\begin{array}{c}\text { CarboPac } \\
\text { PA1 }\end{array}$ & $\mathrm{NaOH}, \mathrm{CH}_{3} \mathrm{COONa}$ & {$[42]$} \\
\hline
\end{tabular}


Table 3: Continued.

\begin{tabular}{|c|c|c|c|c|}
\hline Food sample & Analytes & Column & Eluent & Ref. \\
\hline Onions & Fructooligosaccharides (FOSs) & $\begin{array}{l}\text { CarboPac } \\
\text { PA1 }\end{array}$ & $\mathrm{NaOH}, \mathrm{CH}_{3} \mathrm{COONa}$ & {$[43]$} \\
\hline Prebiotic mixture & Galactooligosaccharides (GOSs) & $\begin{array}{l}\text { CarboPac } \\
\text { PA1 }\end{array}$ & $\mathrm{NaOH}, \mathrm{CH}_{3} \mathrm{COONa}$ & {$[44]$} \\
\hline Rice husk & Maltodextrins & $\begin{array}{l}\text { CarboPac } \\
\text { PA1 }\end{array}$ & $\mathrm{NaNO}_{3}$ & {$[45]$} \\
\hline Rice bran (defatted) & Oligosaccharides & $\begin{array}{l}\text { CarboPac } \\
\text { PA1, PA10 }\end{array}$ & $\mathrm{NaOH}, \mathrm{NaNO}_{3}$ & {$[46]$} \\
\hline Rice husk & Xylooligosaccharides (XOSs) & $\begin{array}{l}\text { CarboPac } \\
\text { PA1 }\end{array}$ & $\mathrm{NaOH}, \mathrm{CH}_{3} \mathrm{COONa}$ & {$[47]$} \\
\hline Rice husk & Xylooligosaccharides (XOSs), & $\begin{array}{l}\text { CarboPac } \\
\text { PA1 }\end{array}$ & $\mathrm{NaOH}, \mathrm{CH}_{3} \mathrm{COONa}$ & {$[48]$} \\
\hline Soybean & $\begin{array}{l}\text { Glucose, fructose, sucrose, } \\
\text { raffinose, stachyose }\end{array}$ & $\begin{array}{l}\text { CarboPac } \\
\text { PA10 }\end{array}$ & $\mathrm{NaOH}$ & {$[49]$} \\
\hline Soybean flour (defatted) & Monosaccharides & $\begin{array}{l}\text { CarboPac } \\
\text { PA1 }\end{array}$ & $\mathrm{NaOH}$ & {$[50]$} \\
\hline Sugar beet & Arabinooligosaccharides (AOSs) & $\begin{array}{l}\text { CarboPac } \\
\text { PA1 }\end{array}$ & $\mathrm{NaOH}$ & {$[51]$} \\
\hline Sugar beet & $\begin{array}{c}\text { Monosaccharides, } \\
\text { arabinooligosaccharides (AOSs), } \\
\text { oligosaccharides }\end{array}$ & $\begin{array}{l}\text { CarboPac } \\
\text { PA1 }\end{array}$ & $\mathrm{NaOH}, \mathrm{CH}_{3} \mathrm{COONa}$ & {$[52]$} \\
\hline Sugar beet & Oligosaccharides & $\begin{array}{l}\text { CarboPac } \\
\text { PA1 }\end{array}$ & $\mathrm{NaOH}, \mathrm{CH}_{3} \mathrm{COONa}$ & {$[53]$} \\
\hline Sugar Beet & $\begin{array}{c}\text { Arabinose and } \\
\text { arabinooligosaccharides (AOSs) }\end{array}$ & $\begin{array}{l}\text { CarboPac } \\
\text { PA1 }\end{array}$ & $\mathrm{NaOH}, \mathrm{CH}_{3} \mathrm{COONa}$ & {$[54]$} \\
\hline Wheat bran, chicory root & $\begin{array}{c}\text { Arabinoxylooligosaccharides } \\
\text { (AOSs), xylooligosaccharides } \\
\text { (XOSs), fructooligosaccharides } \\
\text { (FOSs) }\end{array}$ & $\begin{array}{l}\text { CarboPac } \\
\text { PA100 }\end{array}$ & $\mathrm{NaOH}, \mathrm{CH}_{3} \mathrm{COONa}$ & {$[55]$} \\
\hline Wheat flour & Arabinoxylans & $\begin{array}{l}\text { CarboPac } \\
\text { PA1 } \\
\end{array}$ & $\mathrm{NaOH}$ & {$[56]$} \\
\hline Wheat milling fractions & Fructans & $\begin{array}{l}\text { CarboPac } \\
\text { PA1 }\end{array}$ & $\mathrm{NaOH}, \mathrm{CH}_{3} \mathrm{COONa}$ & {$[10]$} \\
\hline
\end{tabular}

physicochemical and mechanical properties as well as their stability is of pivotal importance for the formulation of new products. In this paper oligo- and polysaccharide distribution of three different inulins has been characterized by HPAEC-PED and has showed that chemical structure of the tested inulins significantly affected the stability, the texture, and the thermal properties of the gels.

Inulin is usually derived from chicory roots. Other promising crops for this production seem to be the Jerusalem artichoke and cereals of $\mathrm{C}_{3}$ type. The metabolism of FOS during the maturation of wheat kernels has been investigated and characterized by HPAEC-, and some biological effects have been studied [62]. FOS and inulin differ for the degree of polymerization and molecular weight, depending on the source, the harvest time, and the processing conditions. Commercial inulin and FOS are extracted by vegetables and are composed by a polydisperse mixture of chains characterized by differences in ramification and chain length. The employment of inulin in food industry requires a preliminary fractionation to obtain products with a defined range of DP. This treatment is usually realized using specific enzymes. Artichoke is a common source of inulin with an average DP around 80; its composition has been recently studied by Ronkart et al. [25] who isolated and purified several fractions with the aim of producing oligomer standards for their identification in a complex inulin chromatogram.

Despite the advantages of HPAEC-PED, the main limit of this technique is related to the lack of commercial standards for chains with high DP. Therefore the peak identification is obviously difficult to be performed, and peak assignment is often based on a generally accepted assumption that the retention time of a homologous series of carbohydrates increases as the DP increases. It means each peak eluted represents a chain with one more unit than the previous peak. Mass spectrometry could be of help in the attribution of the DP of a fraction, and MALDI-TOF has been used successfully for molecular sizing of carbohydrates and to determine chain length distribution of commercial FOS and inulin largely employed as food ingredients [34]. Comparing the two techniques, it has been shown that HPAEC-PED 


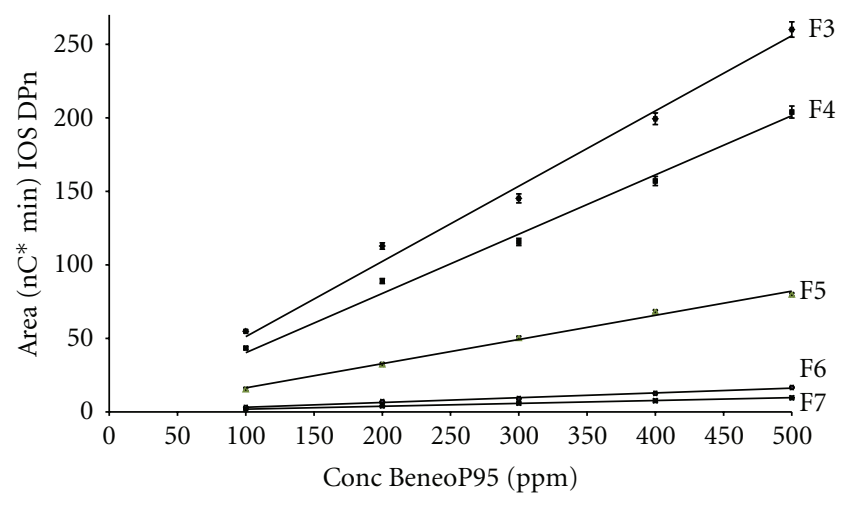

FIGURE 3: Calibration curves built by injecting different concentrations of the commercial mixture of oligosaccharides Beneo (from $[8])$.

allows the record of a profile showing a single peak for each FOS at any DP (even for branched isomers) and the simultaneous analysis of simple sugars and fructans at the same time. On the other hand, MALDI-TOF permits the characterization of molar mass giving details on maximum DP and on every chain present in the samples, although no information on branched and linear isomers can be obtained. Therefore the two techniques can be considered complementary.

As for the quantitative approach, HPAEC-PED is limited to studies involving the use of lab-synthesized standards or methods employing a common external standards to be used for all peaks. This last system does not overcome the inconvenient represented by the variation of detector response with the increasing retention time above discussed. We studied this matter evaluating the differences of slope for calibration curves built by injecting different concentration of a commercial mixture of oligosaccharides containing compounds having different DP [35]. In Figure 3 the different calibration curves obtained for peaks representing chains with DP between 3 and 7 are reported, and the difference in the slope value is evident. A mathematical formula has been proposed [8] permitting to calculate the amount of each compound taking into account the different value of detector response that can be calculated with the aim of an internal standard. Another approach has been proposed by Abballe and coworkers [60], based on the complementary employment of both HPAEC-PED and capillary electrophoresis (CEs) coupled with UV detection and has been applied to verify the reliability of HPAEC-PED for quantitative evaluation of dextran mixtures.

In a recent review from Raessler et al. [63] on the determination of carbohydrates in plant samples, the role of HPAEC-PAD in the analysis of different classes of sugars has been pointed out, and several applications in that field have been reported. The same review presents an overview of the common sample pretreatments, among which hydrolysis of oligo- and polysaccharides that can be performed by acid treatment or by employment of enzymes. The use of enzymes can be useful for conformational studies since it permits a cleavage of selective linkages as in the case of branched oligosaccharides.

As presented in Table 3, many s of foods containing sugars have been analysed by HPAEC-PED. One of the main sugar sources is undoubtedly sugar beet, rich in sucrose but also containing many other carbohydrates. The presence of arabinooligosaccharides with different degrees of polymerization, together with the monosaccharidic profile, has been studied by Zaidel et al. [51] who investigated the presence of branched and linear forms. Sugar beet pulp is a byproduct of the sugar industry abundant in many countries, and it is very rich in pectin, a complex polysaccharide composed by homogalacturonan, and rhamnogalacturonans. It can be a good source for prebiotic production after a controlled enzymatic treatment. Martínez et al. [53] investigated this possibility analyzing the profile of the raw material and of the product of its hydrolysis. Westphal et al. [54] characterized the structure of the chains with the help of NMR studies, while Holck et al. [52] evaluated the in vitro prebiotic activity of different fractions of beet pulp extracts on human intestinal microbiota.

The stability of FOS, arabinoxylooligosaccharides, and xylooligosaccharides during shelf-life has also been investigated by Courtin et al. [55] considering different temperatures and different $\mathrm{pH}$ for different time periods and observing the decomposition of the chains due to the cleavage of the units under the extreme conditions.

Some authors investigated the composition of arabinoxylan, the predominant cell-wall polysaccharides occurring in wheat flour. A comparison of different wheat flours has also been proposed evaluating the effect of processing the content and the structure of water-extractable arabinoxylans [56]. A study on the fructan content in milling fractions and outer part of wheat in two different cultivars has been object of analysis by Haskå et al. [10]. The chromatograms reported in Figure 5 show several differences observed between germ and wheat grain extracts. Isolation, identification, and determination of molecular weight of fructans were evaluated by MALDI-TOF. Using the complementarity of HPLC-PAD and MALDI-TOF, as previously reported [34], the DP of the latest fructan peak was estimated to be 19. Another study was focused on the monosaccharide composition of soybean defatted flour, after acid and enzymatic hydrolysis, and differences between the considered varieties were found [50].

Onion bulbs represent another common vegetable rich in fructooligosaccharides; the profile of those compounds, analysed by HPAEC-PAD, has been found variable among different cultivars, dependent on the bulb size and on storage conditions and time. An interesting study has been developed on onions var. Tropeana harvested in different moments along bulb maturation, and a different pattern of FOS has been found [43]. Similarly, Ghedini Der Agopian et al. [26] analyzed FOS in banana of different cultivars and at different ripening stages, and another study of that kind has been conducted on Agave Americana by Arrizon et al. [24]. Fructans from Agave have been also analyzed by Ávila-Fernández [22] and Ravenscroft et al. [23], who made structural studies using also NMR and ESI-MS techniques. 


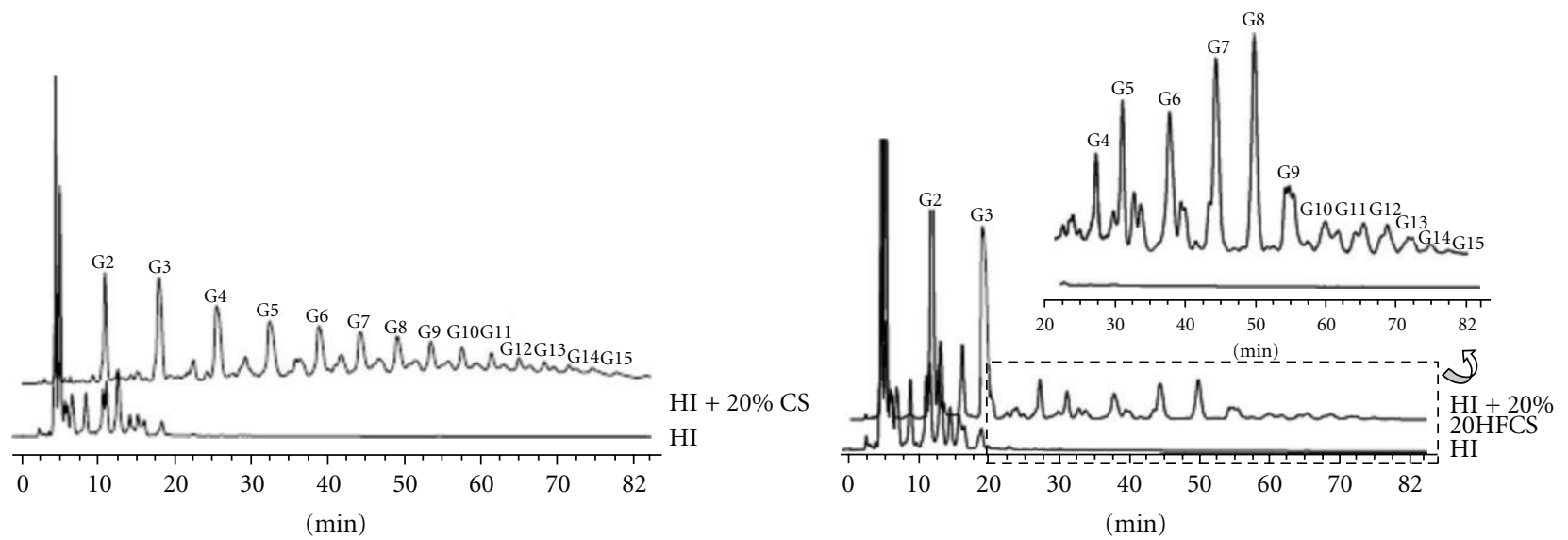

(a)

(b)

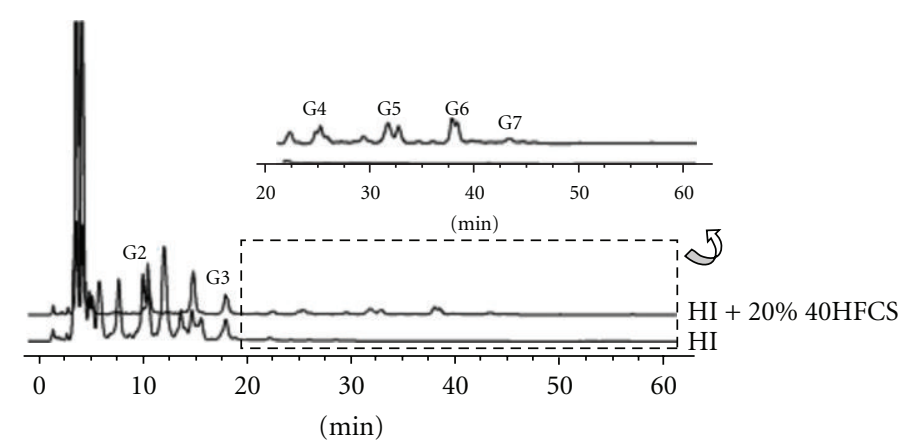

(c)

FIGURE 4: HPAEC-PED chromatographic profiles of the oligosaccharides fraction of a honey sample (H1) and the same sample adulterated with $20 \%$ of (a) corn syrups (CS); (b) high fructose corn syrups with $20 \%$ of isomerization (20HFCS); (c) high fructose corn syrups with $20 \%$ of isomerization (40HFCS). (From [9].)

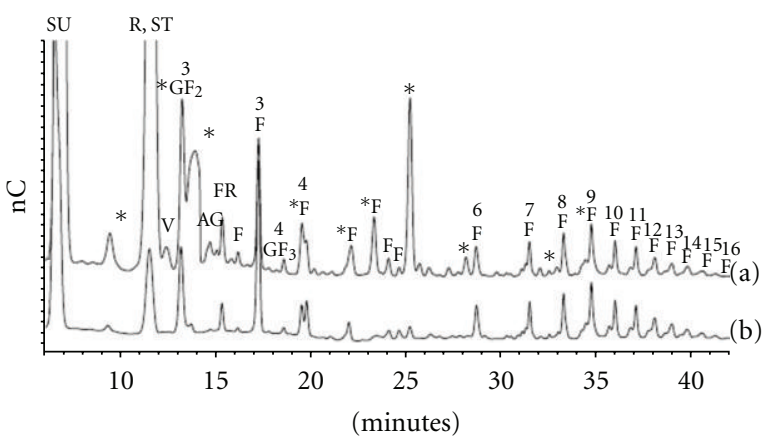

Figure 5: HPAEC-PAD profiles of extracts from (a) germ and (b) wheat grain. SU, sucrose; R, raffinose; ST, stachyose; V, verbascose; GF2, 1-kestose; AG, unidentified a-galactoside; FR, fructosylraffinose; GF3, 1,1-kestotetraose; F, unidentified fructan; *, unidentified non-fructan compound. Numbers indicate DP of fructans. (From [10]).

In the field of food quality control, the origin of a product can be investigated by the analysis of the carbohydrate profile. An example can be honey characterization: the analysis of carbohydrates in honey represents an extremely complicated case for HPAEC-PED analysis because of the number of oligosaccharides present, their relatively low concentration, and their very similar structures, especially regarding the di- and trisaccharide fractions useful for floral origin characterization [64]. A recent study has been proposed by Ouchemoukh et al. [39] who analyzed several honey samples of different botanical origin finding differences in the sugar profiles. A similar approach, based on the examination of the carbohydrate profile, has been shown to be of great help for discovering food adulteration in the case of addition of corn syrup in honey $[9,38,39]$. In Figure 4 the chromatograms obtained by Morales et al. [9], for a honey sample adulterated with corn syrups are reported.

The detection of honey adulteration by addition of cane or beet sugars and/or sugars obtained from starch hydrolysis is particularly difficult because the variations in honey carbohydrates and the similarities with sugar syrups composition make it difficult to detect these adulterations.

Carbohydrate analysis has been demonstrated to be useful in monitoring the eventual changes observed during food storage. An example is the study of the effect of a preliminary treatment of grape berries with $\mathrm{CO}_{2}$, found to influence the sugar profile of grape stored at low temperature [37]. Similarly, synbiotic milks, containing prebiotics and 
probiotics, have been studied during their shelf-life; in particular, a parallel study on the simultaneous variations of the fructooligosaccaridic profile and probiotics microorganisms count has been carried out [35]. The obtained data permitted to evaluate the microbial activity occurring in the product. A similar study on fermented milks has been conducted on galactooligosaccharides (GOSs) [33], where prebiotic GOS content has been determined by HPAEC-PED by using an external calibration curve with raffinose as standard reference.

Recently, $\mathrm{N}$-acetylneuraminic acid and $\mathrm{N}$-glycolylneuraminic acid have been determined by HPAEC-PED in yogurt, milk, and powdered milk [65]. N-acetylneuraminic acid, also known as sialic acid, has been the recipient of considerable attention in recent years regarding the possibility to be added to different kinds of food products for improving health.

In conclusion, as widely reported, pulsed amperometric detection combined with anion exchange chromatography provides a sensitive and selective means of determining simple sugars and more complex carbohydrates in food matrices.

This review of papers published in the last years proves wide application of HPAEC-PED determination of carbohydrates of food interest and opens large possibilities of applications in routine analysis as well as in research studies.

\section{References}

[1] C. G. Huber and G. K. Bonn, "HPLC of carbohydrates with cation and anion-exchange silica and resin-based stationary phases," in Carbohydrate Analysis, Journal of Chromatography Library, Z. El Rassi, Ed., vol. 58, pp. 147-180, Elsevier, Amsterdam, The Netherlands, 1995.

[2] W. R. LaCourse, "Ion chromatography in food analysis," in Handbook of Food Analysis Instruments, S. Otles, Ed., pp. 161196, CRC press, Taylor and Francis Group, 2009.

[3] F. N. Lamari, R. Kuhn, and N. K. Karamanos, "Derivatization of carbohydrates for chromatographic, electrophoretic and mass spectrometric structure analysis," Journal of Chromatography B, vol. 793, no. 1, pp. 15-36, 2003.

[4] T. J. Paskach, H. P. Lieker, P. J. Reilly, and K. Thielecke, "Highperformance anion-exchange chromatography of sugars and sugar alcohols on quarternary ammonium resins under alkaline conditions," Carbohydrate Research, vol. 215, no. 1, pp. $1-14,1991$.

[5] T. R. I. Cataldi, G. Margiotta, and C. G. Zambonin, "Determination of sugars and alditols in food samples by HPAEC with integrated pulsed amperometric detection using alkaline eluents containing barium or strontium ions," Food Chemistry, vol. 62, no. 1, pp. 109-115, 1998.

[6] C. Corradini, D. Corradini, C. G. Huber, and G. K. Bonn, "Synthesis of a polymeric-based stationary phase for carbohydrate separation by high-pH anion-exchange chromatography with pulsed amperometric detection," Journal of Chromatography A, vol. 685, no. 2, pp. 213-220, 1994.

[7] K. S. Wong and J. Jane, "Effects of pushing agents on the separation and detection of debranched amylopectin by highperformance anion-exchange chromatography with pulsed amperometric detection," Journal of Liquid Chromatography, vol. 18, no. 1, pp. 63-80, 1995.

[8] C. Borromei, A. Cavazza, C. Merusi, and C. Corradini, "Characterization and quantitation of short-chain fructooligosaccharides and inulooligosaccharides in fermented milks by high-performance anion-exchange chromatography with pulsed amperometric detection," Journal of Separation Science, vol. 32, no. 21, pp. 3635-3642, 2009.

[9] V. Morales, N. Corzo, and M. L. Sanz, "HPAEC-PAD oligosaccharide analysis to detect adulterations of honey with sugar syrups," Food Chemistry, vol. 107, no. 2, pp. 922-928, 2008.

[10] L. Haskå, M. Nyman, and R. Andersson, "Distribution and characterisation of fructan in wheat milling fractions," Journal of Cereal Science, vol. 48, no. 3, pp. 768-774, 2008.

[11] M. Trojanowicz, "Recent developments in electrochemical flow detections-a review-part II. Liquid chromatography," Analytica Chimica Acta, vol. 688, no. 1, pp. 8-35, 2011.

[12] W. R. LaCourse, "Origins of pulsed potential cleaning," in Pulsed Electrochemical Detection in High Performance Liquid Chromatography, pp. 6-8, John Wiley \& Sons, New York, NY, USA, 1997.

[13] S. Hughes, P. Lawrence Meschi, and D. C. Johnson, "Amperometric detection of simple alcohols in aqueous solutions by application of a triple-pulse potential waveform at platinum electrodes," Analytica Chimica Acta, vol. 132, no. C, pp. 1-10, 1981.

[14] S. Hughes and D. C. Johnson, "Amperometric detection of simple carbohydrates at platinum electrodes in alkaline solutions by application of a triple-pulse potential waveform," Analytica Chimica Acta, vol. 132, no. C, pp. 11-22, 1981.

[15] D. C. Johnson and W. R. LaCourse, "Pulsed electrochemical detection of carbohydrates at gold electrodes following liquid chromatographic separation," in Carbohydrate Analysis, Journal of Chromatography Library, Z. El Rassi, Ed., vol. 58, pp. 391-429, Elsevier, Amsterdam, The Netherlands, 1995.

[16] D. C. Johnson and W. R. LaCourse, "Pulsed electrochemical detection at noble metal electrodes in liquid chromatography," Electroanalysis, vol. 4, pp. 367-380, 1992.

[17] R. D. Rocklin, A. P. Clarke, and M. Weitzhandler, "Improved long-term reproducibility for pulsed amperometric detection of carbohydrates via a new quadruple-potential waveform," Analytical Chemistry, vol. 70, no. 8, pp. 1496-1501, 1998.

[18] T. R. I. Cataldi, C. Campa, and G. E. De Benedetto, "Carbohydrate analysis by high-performance anion-exchange chromatography with pulsed amperometric detection: the potential is still growing," Fresenius' Journal of Analytical Chemistry, vol. 368, no. 8, pp. 739-758, 2000.

[19] Z. El Rassi, "Carbohydrate analysis by modern chromatography and electrophoresis," in Journal of Chromatography Library, Z. El Rassi, Ed., vol. 66, Elsevier Science, Amsterdam, The Netherlands, 2002.

[20] A. Cardelle-Cobas, N. Corzo, M. Villamiel, and A. Olano, "Isomerization of lactose-derived oligosaccharides: a case study using sodium aluminate," Journal of Agricultural and Food Chemistry, vol. 56, no. 22, pp. 10954-10959, 2008.

[21] M. Brokl, O. Hernández-Hernández, A. C. Soria, and M. L. Sanz, "Evaluation of different operation modes of high performance liquid chromatography for the analysis of complex mixtures of neutral oligosaccharides," Journal of Chromatography A, vol. 1218, no. 42, pp. 7697-7703, 2011.

[22] A. Ávila-Fernández, N. Galicia-Lagunas, M. E. RodríguezAlegría, C. Olvera, and A. López-Munguía, "Production of functional oligosaccharides through limited acid hydrolysis of agave fructans," Food Chemistry, vol. 129, no. 2, pp. 380-386, 2011.

[23] N. Ravenscroft, P. Cescutti, M. A. Hearshaw, R. Ramsout, R. Rizzo, and E. M. Timme, "Structural analysis of fructans from agave americana grown in South Africa for spirit production," 
Journal of Agricultural and Food Chemistry, vol. 57, no. 10, pp. 3995-4003, 2009.

[24] J. Arrizon, S. Morel, A. Gschaedler, and P. Monsan, "Comparison of the water-soluble carbohydrate composition and fructan structures of Agave tequilana plants of different ages," Food Chemistry, vol. 122, no. 1, pp. 123-130, 2010.

[25] S. N. Ronkart, C. S. Blecker, H. Fourmanoir et al., "Isolation and identification of inulooligosaccharides resulting from inulin hydrolysis," Analytica Chimica Acta, vol. 604, no. 1, pp. 81-87, 2007.

[26] R. G. Der Agopian, C. A. Soares, E. Purgatto, B. R. Cordenunsi, and F. M. Lajolo, "Identification of fructooligosaccharides in different banana cultivars," Journal of Agricultural and Food Chemistry, vol. 56, no. 9, pp. 3305-3310, 2008.

[27] D. H. Yoo, B. H. Lee, P. S. Chang, G. L. Hyeon, and S. H. Yoo, "Improved quantitative analysis of oligosaccharides from lichenase-hydrolyzed water-soluble barley $\beta$-glucans by high-performance anion-exchange chromatography," Journal of Agricultural and Food Chemistry, vol. 55, no. 5, pp. 1656$1662,2007$.

[28] J. Treimo, B. Westereng, S. J. Horn et al., "Enzymatic solubilization of brewers' spent grain by combined action of carbohydrases and peptidases," Journal of Agricultural and Food Chemistry, vol. 57, no. 8, pp. 3316-3324, 2009.

[29] M. Mosca, C. Boniglia, B. Carratù, S. Giammarioli, V. Nera, and E. Sanzini, "Determination of $\alpha$-amylase inhibitor activity of phaseolamin from kidney bean (Phaseolus vulgaris) in dietary supplements by HPAEC-PAD," Analytica Chimica Acta, vol. 617, no. 1-2, pp. 192-195, 2008.

[30] N. Kawazoe, H. Okada, E. Fukushi et al., "Two novel oligosaccharides isolated from a beverage produced by fermentation of a plant extract," Carbohydrate Research, vol. 343, no. 3, pp. 549-554, 2008.

[31] H. Okada, E. Fukushi, A. Yamamori et al., "Novel fructopyranose oligosaccharides isolated from fermented beverage of plant extract," Carbohydrate Research, vol. 345, no. 3, pp. 414418, 2010.

[32] H. Okada, E. Fukushi, A. Yamamori et al., "Isolation and structural confirmation of the oligosaccharides containing $\alpha$ $\mathrm{d}$-fructofuranoside linkages isolated from fermented beverage of plant extracts," Carbohydrate Research, vol. 346, no. 16, pp. 2633-2637, 2011.

[33] C. Martínez-Villaluenga, A. Cardelle-Cobas, N. Corzo, and A. Olano, "Study of galactooligosaccharide composition in commercial fermented milks," Journal of Food Composition and Analysis, vol. 21, no. 7, pp. 540-544, 2008.

[34] C. Borromei, M. Careri, A. Cavazza et al., "Evaluation of fructooligosaccharides and inulins as potentially health benefiting food ingredients by HPAEC-PED and MALDI-TOF MS," International Journal of Analytical Chemistry, vol. 2009, Article ID 530639, 9 pages, 2009.

[35] C. Borromei, A. Cavazza, C. Corradini et al., "Validated HPAEC-PAD method for prebiotics determination in synbiotic fermented milks during shelf life," Analytical and Bioanalytical Chemistry, vol. 397, no. 1, pp. 127-135, 2010.

[36] M. Feinberg, J. San-Redon, and A. Assié, "Determination of complex polysaccharides by HPAE-PAD in foods: validation using accuracy profile," Journal of Chromatography B, vol. 877, no. 23, pp. 2388-2395, 2009.

[37] M. Blanch, M. T. Sanchez-Ballesta, M. I. Escribano, and C. Merodio, "Fructo-oligosaccharides in table grapes and response to storage," Food Chemistry, vol. 129, no. 3, pp. 724$730,2011$.
[38] V. Morales, M. L. Sanz, A. Olano, and N. Corzo, "Rapid separation on activated charcoal of high oligosaccharides in honey," Chromatographia, vol. 64, no. 3-4, pp. 233-238, 2006.

[39] S. Ouchemoukh, P. Schweitzer, M. Bachir Bey, H. DjoudadKadji, and H. Louaileche, "HPLC sugar profiles of Algerian honeys," Food Chemistry, vol. 121, no. 2, pp. 561-568, 2010.

[40] M. Megherbi, B. Herbreteau, R. Faure, and A. Salvador, "Polysaccharides as a marker for detection of corn sugar syrup addition in honey," Journal of Agricultural and Food Chemistry, vol. 57, no. 6, pp. 2105-2111, 2009.

[41] P. Girard, P. Stöber, M. Blanc, and J. Prodolliet, "Carbohydrate specification limits for the authenticity assessment of soluble (Instant) Coffee: statistical approach," Journal of the Association of Official Agricultural Chemists, vol. 89, no. 4, pp. 9991003, 2006.

[42] S. Albrecht, G. C. J. Van Muiswinkel, H. A. Schols, A. G. J. Voragen, and H. Gruppen, "Introducing capillary electrophoresis with laser-induced fluorescence detection (CE-LIF) for the characterization of konjac glucomannan oligosaccharides and their in vitro fermentation behavior," Journal of Agricultural and Food Chemistry, vol. 57, no. 9, pp. 3867-3876, 2009.

[43] A. Cavazza, C. Corradini, M. Giannetto, R. Greco, G. Mori, and T. Vicchio, "Studio del profilo di fruttooligosaccaridi in cipolle di diversa cultivar mediante HPAEC-PAD: valutazione chemiometrica," in Proceedings of the VIII Congresso Nazionale di Chimica degli Alimenti, pp. 550-553, Marsala, Italy, 2010.

[44] L. Coulier, J. Timmermans, B. Richard et al., "In-depth characterization of prebiotic galactooligosaccharides by a combination of analytical techniques," Journal of Agricultural and Food Chemistry, vol. 57, no. 18, pp. 8488-8495, 2009.

[45] J. Patindol, Y. J. Wang, and J. L. Jane, "Structure-functionality changes in starch following rough rice storage," Starch/Staerke, vol. 57, no. 5, pp. 197-207, 2005.

[46] J. Patindol, L. Wang, and Y. J. Wang, "Cellulase-assisted extraction of oligosaccharides from defatted rice bran," Journal of Food Science, vol. 72, no. 9, pp. C516-C521, 2007.

[47] P. Gullón, P. Moura, M. P. Esteves, F. M. Girio, H. Domínguez, and J. C. Parajó, "Assessment on the fermentability of xylooligosaccharides from rice husks by probiotic bacteria," Journal of Agricultural and Food Chemistry, vol. 56, no. 16, pp. 7482-7487, 2008.

[48] P. Gullón, M. J. González-Muñoz, M. P. van Gool et al., "Production, refining, structural characterization and fermentability of rice husk xylooligosaccharides," Journal of Agricultural and Food Chemistry, vol. 58, no. 6, pp. 3632-3641, 2010.

[49] E. Giannoccaro, Y. J. Wang, and P. Chen, "Comparison of two HPLC systems and an enzymatic method for quantification of soybean sugars," Food Chemistry, vol. 106, no. 1, pp. 324-330, 2008.

[50] E. M. Bainy, S. M. Tosh, M. Corredig, V. Poysa, and L. Woodrow, "Varietal differences of carbohydrates in defatted soybean flour and soy protein isolate by-products," Carbohydrate Polymers, vol. 72, no. 4, pp. 664-672, 2008.

[51] D. N. A. Zaidel, A. Arnous, J. Holck, and A. S. Meyer, "Kinetics of enzyme-catalyzed cross-linking of feruloylated arabinan from sugar beet," Journal of Agricultural and Food Chemistry, vol. 59, no. 21, pp. 11598-11607, 2011.

[52] J. Holck, A. Lorentzen, L. K. Vigsnæs, T. R. Licht, J. D. Mikkelsen, and A. S. Meyer, "Feruloylated and nonferuloylated arabino-oligosaccharides from sugar beet pectin selectively stimulate the growth of bifidobacterium spp. In human fecal in vitro fermentations," Journal of Agricultural and Food Chemistry, vol. 59, no. 12, pp. 6511-6519, 2011. 
[53] M. Martínez, B. Gullón, R. Yáñez, J. L. Alonso, and J. C. Parajó, "Direct enzymatic production of oligosaccharide mixtures from sugar beet pulp: experimental evaluation and mathematical modeling," Journal of Agricultural and Food Chemistry, vol. 57, no. 12, pp. 5510-5517, 2009.

[54] Y. Westphal, S. Kühnel, P. de Waard et al., "Branched arabino-oligosaccharides isolated from sugar beet arabinan," Carbohydrate Research, vol. 345, no. 9, pp. 1180-1189, 2010.

[55] C. M. Courtin, K. Swennen, P. Verjans, and J. A. Delcour, "Heat and $\mathrm{pH}$ stability of prebiotic arabinoxylooligosaccharides, xylooligosaccharides and fructooligosaccharides," Food Chemistry, vol. 112, no. 4, pp. 831-837, 2009.

[56] L. Virkki, H. N. Maina, L. Johansson, and M. Tenkanen, "New enzyme-based method for analysis of water-soluble wheat arabinoxylans," Carbohydrate Research, vol. 343, no. 3, pp. 521-529, 2008.

[57] S. Kolida, K. Tuohy, and G. R. Gibson, "Prebiotic effects of inulin and oligofructose," British Journal of Nutrition, vol. 87, no. 2, pp. S193-S197, 2002.

[58] C. Corradini, F. Bianchi, D. Matteuzzi, A. Amoretti, M. Rossi, and S. Zanoni, "High-performance anion-exchange chromatography coupled with pulsed amperometric detection and capillary zone electrophoresis with indirect ultra violet detection as powerful tools to evaluate prebiotic properties of fructooligosaccharides and inulin," Journal of Chromatography A, vol. 1054, no. 1-2, pp. 165-173, 2004.

[59] M. Rossi, C. Corradini, A. Amaretti et al., "Fermentation of fructooligosaccharides and inulin by bifidobacteria: a comparative study of pure and fecal cultures," Applied and Environmental Microbiology, vol. 71, no. 10, pp. 6150-6158, 2005.

[60] F. Abballe, M. Toppazzini, C. Campa, F. Uggeri, and S. Paoletti, "Study of molar response of dextrans in electrochemical detection," Journal of Chromatography A, vol. 1149, no. 1, pp. 38-45, 2007.

[61] E. Chiavaro, E. Vittadini, and C. Corradini, "Physicochemical characterization and stability of inulin gels," European Food Research and Technology, vol. 225, no. 1, pp. 85-94, 2007.

[62] N. Merendino, M. D’Aquino, R. Molinari et al., "Chemical characterization and biological effects of immature durum wheat in rats," Journal of Cereal Science, vol. 43, no. 2, pp. 129136, 2006.

[63] M. Raessler, B. Wissuwa, A. Breul, W. Unger, and T. Grimm, "Determination of water-extractable nonstructural carbohydrates, including inulin, in grass samples with highperformance anion exchange chromatography and pulsed amperometric detection," Journal of Agricultural and Food Chemistry, vol. 56, no. 17, pp. 7649-7654, 2008.

[64] C. Corradini, G. Canali, and I. Nicoletti, "Application of HPAEC-PAD to carbohydrate analysis in food products and fruit juices," Seminars in Food Analysis, vol. 2, pp. 99-111, 1997.

[65] K. T. Tang, L. N. Liang, Y. Q. Cai, and S. F. Mou, "Determination of sialic acid in milk and products using high performance anion-exchange chromatography coupled with pulsed amperometric detection," Fenxi Huaxue/ Chinese Journal of Analytical Chemistry, vol. 36, no. 11, pp. 1535-1538, 2008. 


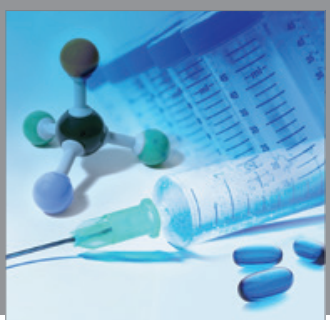

International Journal of

Medicinal Chemistry

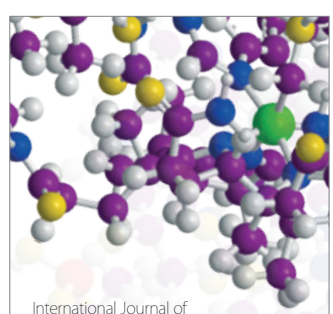

Carbohydrate Chemistry

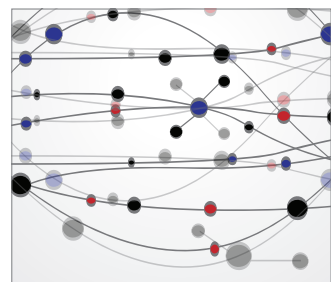

The Scientific World Journal
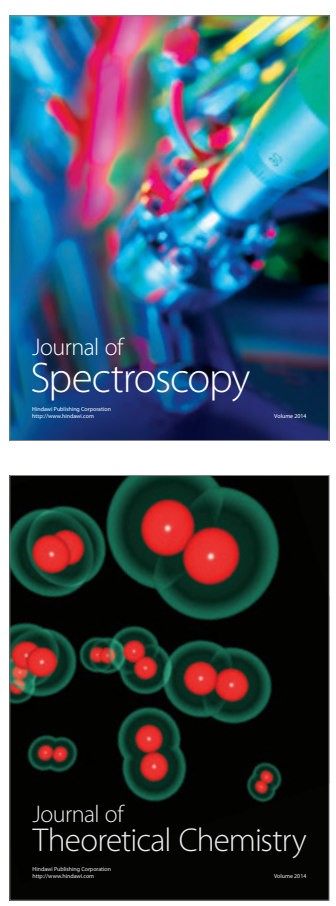
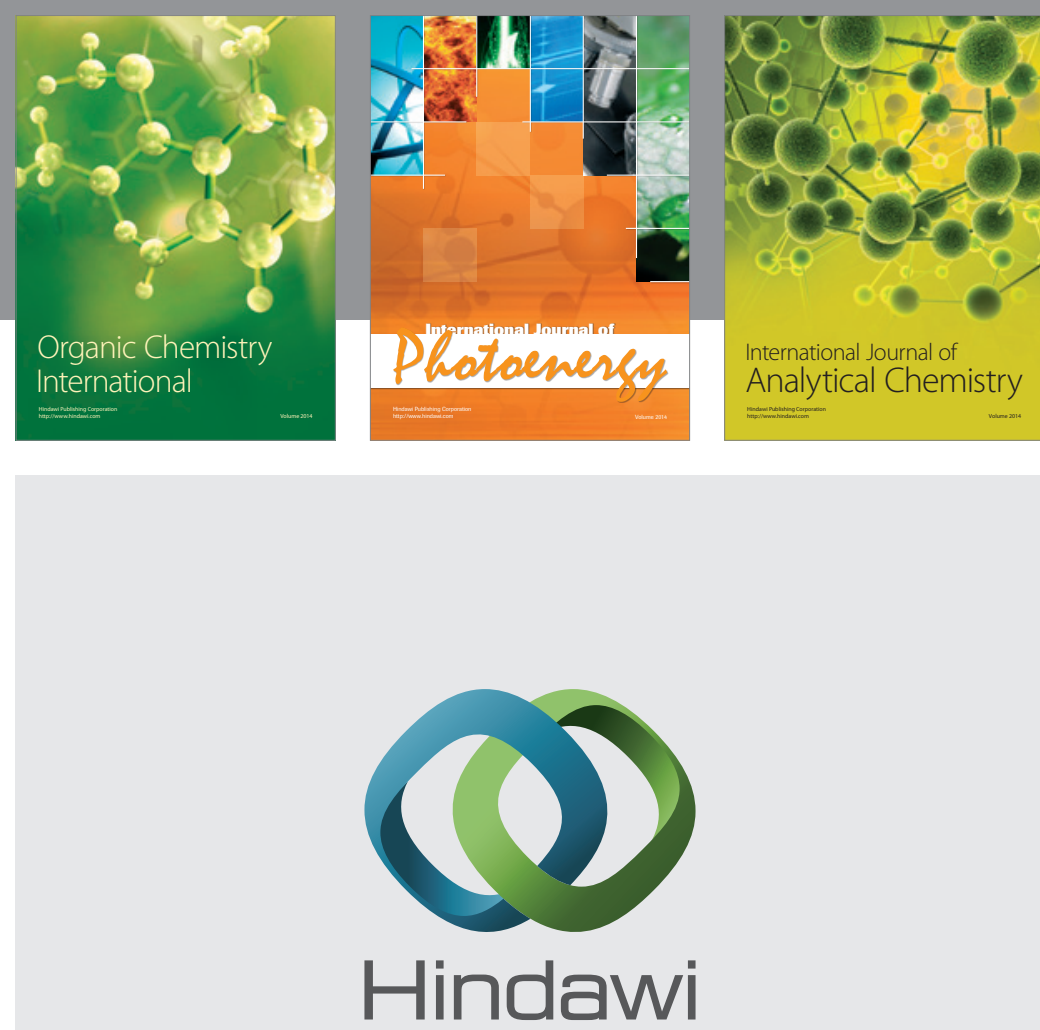

Submit your manuscripts at

http://www.hindawi.com
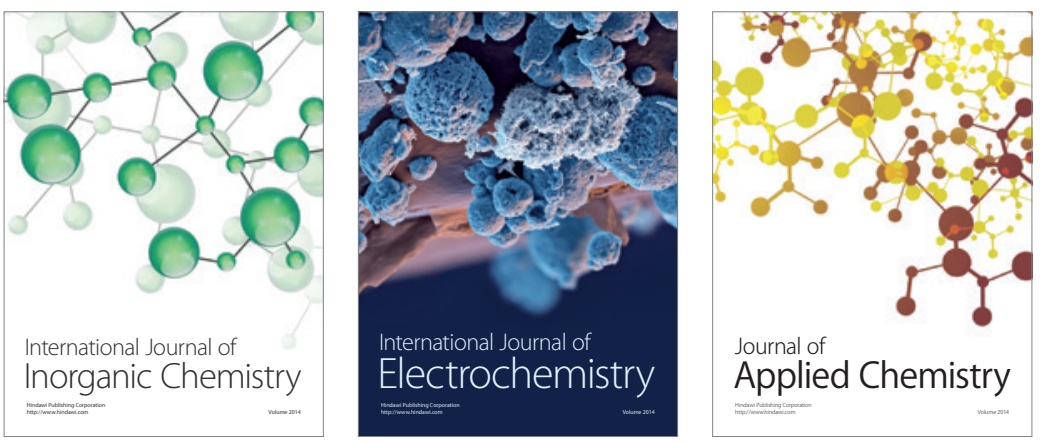

Journal of

Applied Chemistry
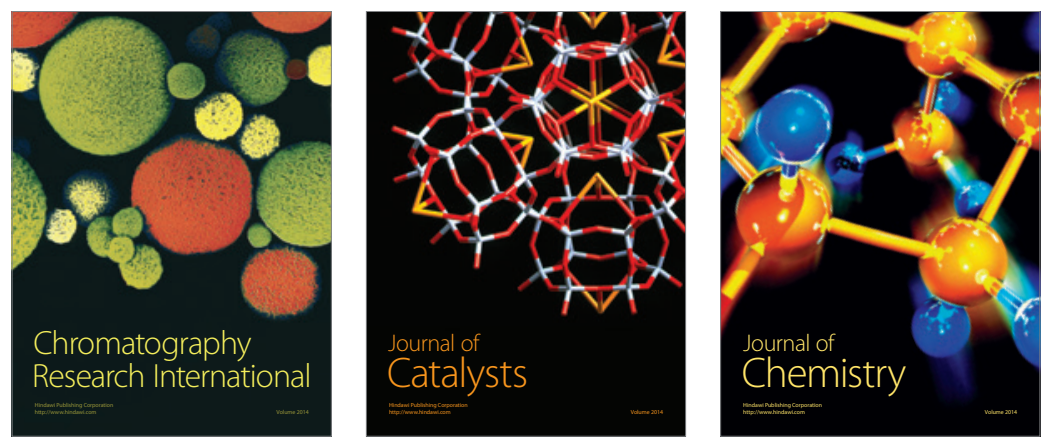
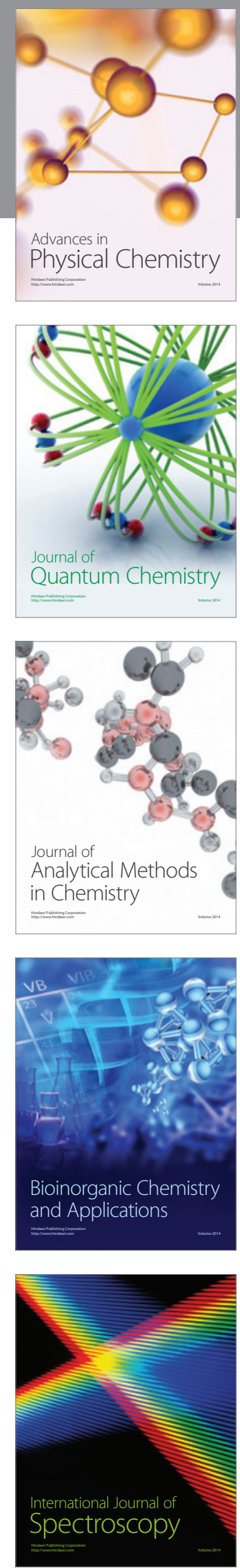